DOI 10.31558/2307-2318.2019.3.9

УДК 658.53 (075)

Сивицька І.Г., доцент кафедри бізнес-статистики та економічної кібернетики ДонНУ імени Василя Стуса

Синиченко А.В., ст.викладач кафедри менеджменту та поведінкової економіки ДонНУ імені Василя Стуса

\title{
МОТИВАЦІЙНА СТРАТЕГІЯ ЯК ПРОВІДНА ДЕТЕРМІНАНТА ОПТИМІЗАЦІї УПРАВЛІННЯ ПЕРСОНАЛОМ
}

У статті обумовлено значимість мотивації персоналу як головного важеля управління персоналом; проведено аналіз різних підходів сучасних наукових шкіл до стратегічного управління мотивацією персоналу; уточнено поняття мотиваційної стратегії як довгострокової програми дій по реалізації концепції використання i розвитку потенціалу персоналу підприємства; розроблено структурно-логічну схему стратегічного управління мотивацією персоналу; доведено, що мотиваційна стратегія $\epsilon$ провідною детермінантою оптимізації управління персоналом і може розглядатися як в контексті загального стратегічного управління підприємством, так і як самостійна функціональна стратегія підприємства; доведено, що дієвість впровадження мотиваційної стратегії зумовлено дотриманням основоположних принципів; запропоновано науково-практичний підхід до розробки мотиваційної стратегії, сутність якого полягає в виокремленні етапів розробки мотиваційної стратегії як системного компоненту при обгрунтуванні загальної стратегії розвитку підприємства, спрямованого на досягнення поставлених цілей.

Ключові слова: мотиваційна стратегія, управління персоналом, мотивація персоналу, оптимізація, мотиваційний потенціал.

\section{Сивицкая І.Г., Синиченко А.В. МОТИВАЦИОННАЯ СТРАТЕГИЯ КАК ВЕДУЩАЯ ДЕТЕРМИНАНТА ОПТИМИЗАЦИИ УПРАВЛЕНИЯ ПЕРСОНАЛОМ}

В статье обусловлено значимость мотивации персонала как главного рычага управления персоналом; проведен анализ различных подходов современных научных школ к стратегическому управлению мотивацией персонала; уточнено понятие мотивационной стратегии как долгосрочной программы действий по реализации концепции использования и развития потенциала персонала предприятия; разработана структурно-логическая схема стратегического управления мотивацией персонала; доказано, что мотивационная стратегия является ведущей детерминантой оптимизации управления персоналом и может рассматриваться как в контексте общего стратегического управления предприятием, так и как самостоятельная функциональная стратегия предприятия; доказано, что действенность внедрения мотивационной стратегии обусловлена соблюдением основополагающих принципов; предложено научно-практический подход к разработке мотивационной стратегии, сущность которого заключается в выделении этапов разработки мотивационной стратегии как системного компонента при обосновании общей стратегии развития предприятия, направленного на достижение поставленных целей.

Ключевые слова: мотивационная стратегия, управление персоналом, мотивация персонала, оптимизация, мотивационный потенциал. 


\section{Sivitskaya I., Sinichenko A. MOTIVATIONAL STRATEGY AS A LEADING DETERMINANT OF HUMAN RESOURCES OPTIMIZATION}

The article determines the importance of staff motivation as the main lever of personnel management; the analysis of various approaches of modern scientific schools to the strategic management of staff motivation; clarified the concept of motivational strategy as a long-term program of actions to implement the concept of using and developing the potential of the personnel of enterprises a structural-logical scheme of strategic management of staff motivation was developed; it is proved that the motivational strategy is the leading determinant of HR optimization and can be considered both in the context of the overall strategic management of the enterprise, and as an independent functional strategy of the enterprise; it is proved that the effectiveness of the introduction of a motivational strategy is due to the observance of fundamental principles; a scientific and practical approach to the development of a motivational strategy is proposed, the essence of which is to single out the stages of developing a motivational strategy as a system component in substantiating the general development strategy of an enterprise aimed at achieving its goals.

Key words: motivational strategy, personnel management, staff motivation, optimization, motivational potential.

Постановка проблеми та її зв'язок з важливими науковими чи практичними завданнями. У сучасній концепції управління персоналом на перший план стали виходити соціально-психологічні методи менеджменту, використання яких спрямовано на перегляд ролі особистості людини, коли вона 3 виконавця праці перетворюється у важливий ресурс підприємства, його інтелектуальний капітал.

Якщо виходити з того, що праця являє собою особливий вид діяльності людини, а діяльність в свою чергу зумовлена дією мотивів як спонукальної сили відтворювального процесу, то виникає необхідність розгляду особливостей мотивації персоналу. У загальному розумінні мотивація - це сукупність рушійних сил, які спонукають людину до виконання певних дій. Ці сили можуть мати як зовнішнє, так і внутрішнє походження і змушувати людину свідомо чи несвідомо виконувати ті або інші дії. Мотив праці формується лише тоді, коли трудова діяльність є якщо не єдиною, то основною умовою отримання блага. Сила мотиву визначається ступенем актуальності певної потреби для працівника. Чим більш нагальна потреба, чим сильніше прагнення отримати благо, тим активніше працює людина.

Особливої актуальності мотивація персоналу набуває в умовах економічного спаду. Адже економічна криза загрожує підприємствам не тільки фінансовими проблемами i ослабленням конкурентних позицій на ринку, але й втратою кваліфікованих фахівців, без яких неможливо успішно вести бізнес. Причому втратити фахівця можна не тільки в прямому сенсі цього слова, а й в переносному, коли знижується його працездатність, ініціативність, віра в завтрашній день, оптимізм.

Мотиваційна сфера особистості не просто ієрархія потреб і мотивів, це ієрархія цілей, стратегічних планів і очікуваних результатів, наявність яких сприяє активізації діяльності людини взагалі і трудової діяльності персоналу, зокрема.

3 огляду на вищевикладене доцільно зробити умовивід про те, що одним із дієвих засобів активізації персоналу підприємства $є$ розробка мотиваційної стратегії. Узагальнюючи аналіз основних положень, пов'язаних з мотиваційною стратегією, слід зауважити, що іiі основною метою є забезпечення необхідних і економічно вигідних 
умов, які максимально сприяють досягненню стратегічних цілей $\mathrm{i}$ очікувань працівників в рамках реалізації базової стратегії розвитку підприємства.

Аналіз останніх досліджень і публікацій 3 проблеми, що розглядається. За останні роки в економічній літературі представлено різні наукові підходи до визначення мотивації та ії ролі в управлінні персоналом, проведено угрупування теорій за критеріями їхнього функціонального призначення та впливу на ефективність управління персоналом [1-7].

Ряд науковців конкретизують проблеми мотивації, розглядаючи певні аспекти мотивації в тому чи іншому контексті. Так Н.В.Ващенко висвітлює проблему посилення мотиваційного впливу в рамках реалізації інноваційного потенціалу персоналу [8]; Я.С.Пицур і А.Р.Черченко досліджують мотивацію як функцію управлінської праці, спрямовану на спонукання персоналу до досягнення найкращих результатів організації [9]; В.А.Любицька проводить аналіз впливу макро-, мезо - та мікрофакторів, що обумовлюють функціонування системи мотивації персоналу [10]; Ю.С.Наумко визначає напрями щодо вдосконалення системи мотивації праці, досліджує зміни, які відбуваються в системі мотивації персоналу [11]; П.Гаудж доводить практичні вигоди від проведення досліджень мотивації персоналу [12] і т.ін.

Визначення окремих питань, що не вирішені. Багатоаспектність досліджень, висвітлених в економічній літературі показує, що проблеми мотивації персоналу в більшості наукових праць, торкаються сьогоденного стану підприємства. Враховуючи мінливість як зовнішнього, так i внутрішнього середовища функціонування підприємства виникає необхідність більш поглибленого вивчення стратегії розвитку підприємства в цілому та мотиваційної стратегії, зокрема.

Формулювання цілей статті. Цілі статті полягають у теоретичному уточненні поняття «мотиваційна стратегія»; узагальненні наукових підходів до стратегічного управління мотивацією персоналу; визначенні науково-практичного підходу до розробки мотиваційної стратегії.

Виклад основного матеріалу. Природа сил, здатних суттєво вплинути на трудову активність персоналу, надзвичайно складна. В найбільш загальному розумінні мотивація може бути визначена як процес, що визначає енергетичну сторону i спрямованість поведінки особистості. Цей внутрішній процес направляє поведінку людини i визначає вибір, який вона робить 3 можливого набору поведінкових альтернатив. Незважаючи на всю важливість і порівняно тривалу історію, дослідження мотивації в поведінкових науках стикаються з багатьма проблемами. Це відбувається, перш за все, тому, що зовнішнє спостереження за мотивацією неможливо. Мотивація не $є$ якимось матеріалізованим фактом, який можна побачити на власні очі чи визначити емпірично. Мотивація - це сукупність внутрішніх і зовнішніх рушійних сил, які спонукають людину до діяльності і додають цій діяльності спрямованість, орієнтовану на досягнення певних цілей.

Мотивація персоналу $є$ головною детермінантою управління персоналом i водночас провідною компонентою процесу управління підприємством в цілому. Ряд вчених-економістів вважає, що найбільш ефективною системою мотивації є мотивація на результат, оскільки саме такий підхід до мотивації персоналу дає можливість працівникам отримувати і збільшувати дохід в чіткій залежності від їхніх зусиль і ступеня трудової активності [13, с.226].

Для формування трудової мотивації персоналу найбільшу значимість має характер засвоєних працівником трудових норм і цінностей, які надають сенс його трудовій діяльності. У професійну трудову діяльність людина вступає 3 уже 
сформованою ціннісною свідомістю. Вона знає, які інтереси хотіла б реалізувати за допомогою праці. Так формується практичний пласт трудової свідомості, обумовлений, 3 одного боку, ціннісними орієнтаціями особистості, а 3 іншого - конкретними обставинами професійного трудового життя. Основна мета трудової мотивації персоналу полягає в стимулюванні виробничого поведінки працівників, орієнтованого на досягнення стратегічних завдань, що стоять перед ними.

Ступінь активності персоналу, його творчий, інноваційний характер залежить від очікування того, що зусилля призведуть до бажаного результату i будуть винагородженні. Якщо цінність винагороди, яку одержує працівник співпадає з його очікуваннями або перевищує їх, то це призводить до посилення його мотивації і як наслідок, виникнення потреб i/aбо мотивів більш високого порядку, збільшенню зусиль, активізації діяльності в напрямку ії удосконалення.

Розробку заходів щодо посилення мотивації персоналу доцільно починати 3 визначення мотиваційної стратегії, яка передбачає певний порядок дій в напрямку стимулювання персоналу, спрямований на підвищення його трудового внеску в підвищення ефективності господарської діяльності підприємства.

Мотиваційна стратегія - це підсистема стратегії підприємства, яка представляє довгострокову програму дій по реалізації концепції використання і розвитку потенціалу персоналу підприємства 3 метою забезпечення його стратегічних конкурентних переваг.

При розробці мотиваційної стратегії доцільно дотримуватися певних принципів, а саме:

-персонал підприємства повинен відчувати визнання свого вкладу в діяльність підприємства;

-за результати праці персонал повинен отримувати справедливу винагороду;

-персонал повинен усвідомлювати особливості діючої системи мотивації персоналу;

-методи мотивації повинні бути зрозумілими та задовольняти основні стимули персоналу до праці.

Розглянемо підходи до розробки мотиваційної стратегії в двох аспектах.

Першим аспектом $є$ розгляд мотиваційної стратегії в контексті загального стратегічного управління підприємством. Як функція управління мотивація трудової діяльності являє собою процес створення у персоналу внутрішнього спонукання до дій для досягнення цілей підприємства у відповідності 3 їхніми посадовими повноваженнями.

Запропонована структурно-логічна схема стратегічного управління мотивацією персоналу представлена на рисунку 1.

Вихідною структурною компонентою стратегічного управління мотивацією персоналу $\epsilon$ визначення місії і цілей підприємств. Надалі алгоритм стратегічного управління мотивацією створюється у відповідності до структури процесу управління: стратегічне планування в системі мотивації персоналу; розробка стратегічного набору щодо розвитку мотиваційного потенціалу; реалізація стратегій і проведення необхідних стратегічних змін; стратегічний контроль в системі мотивації персоналу.

Другий аспект полягає у розгляді мотиваційної стратегії, як однієї 3 функціональних стратегій підприємства. Функціональна стратегія - це більш вузький стратегічний план розвитку підприємства в порівнянні з діловою стратегією, яка конкретизує окремі деталі в загальному плані розвитку підприємства. Таке визначення має включати в себе розробку системи мотивації працівників, для кожної підгрупи. 
Підгрупи формуються за психологічними якостями працівників і їхніми життєвими потребами як у діловій, так і особистісній сфері діяльності. Надалі це дозволить більш ретельно і якісно будувати систему ключових стимулів і мотивів у працівників, i, як наслідок, підвищити продуктивність праці.

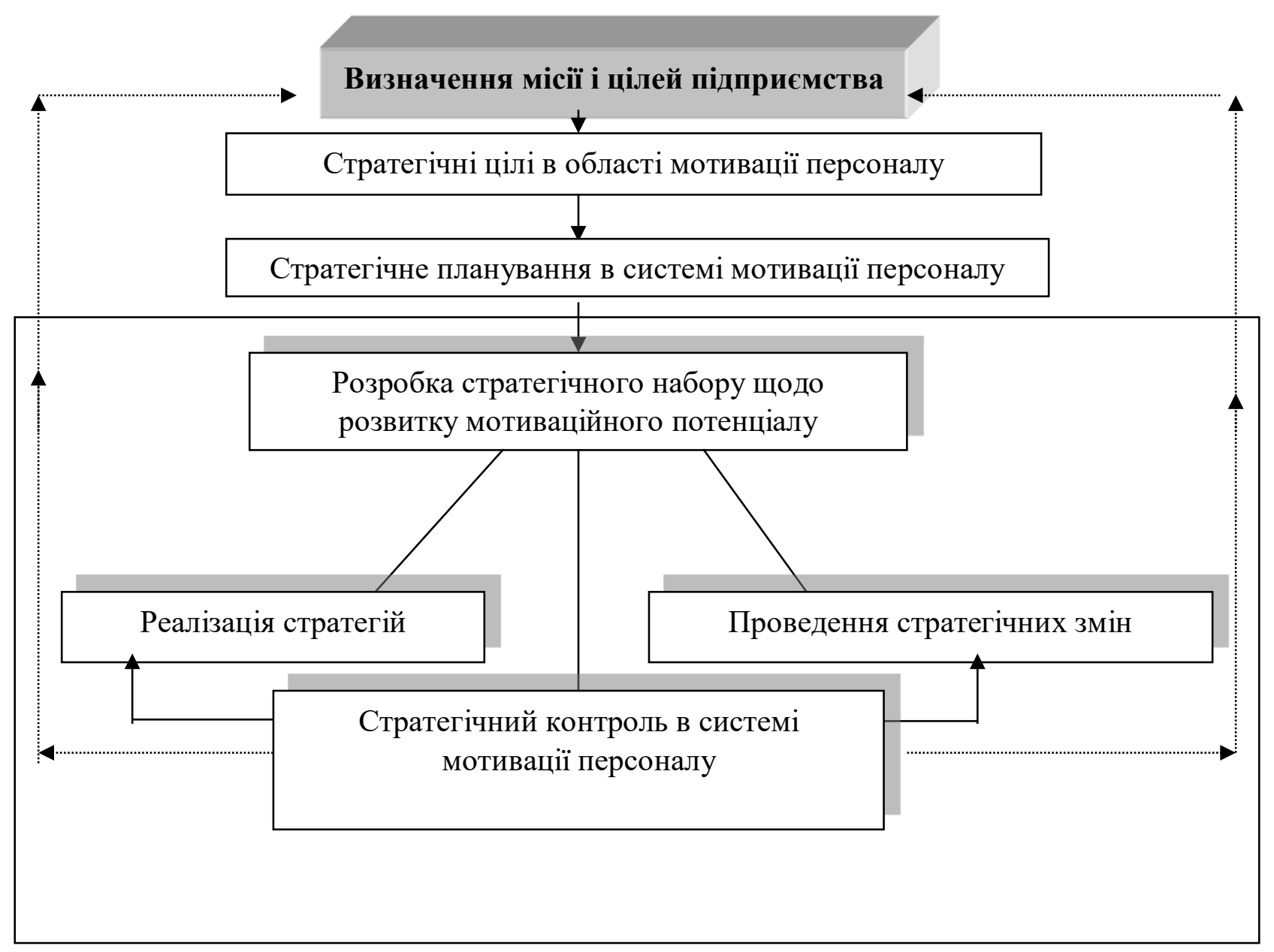

\section{Рисунок 1 - Структурно-логічна схема стратегічного управління мотивацією персоналу \\ *авторська розробка}

Автором запропоновано науково-практичний підхід до розробки мотиваційної стратегії, сутність якого полягає в виокремленні етапів розробки мотиваційної стратегії як системного компоненту при обгрунтуванні загальної стратегії розвитку підприємства, спрямованого на досягнення поставлених цілей (рис.2).

Перш за все необхідно визначити цілі мотивації персоналу у відповідності 3 загальними цілями і стратегією розвитку підприємства. Як основні цілі мотивації персоналу можуть виступати: досягнення цілей підприємства, підвищення ефективності праці, утримання досвідчених та кваліфікованих співробітників, 
стимулювання бажаної організаційної поведінки працюючих, справедливий розподіл фонду оплати праці та ін.

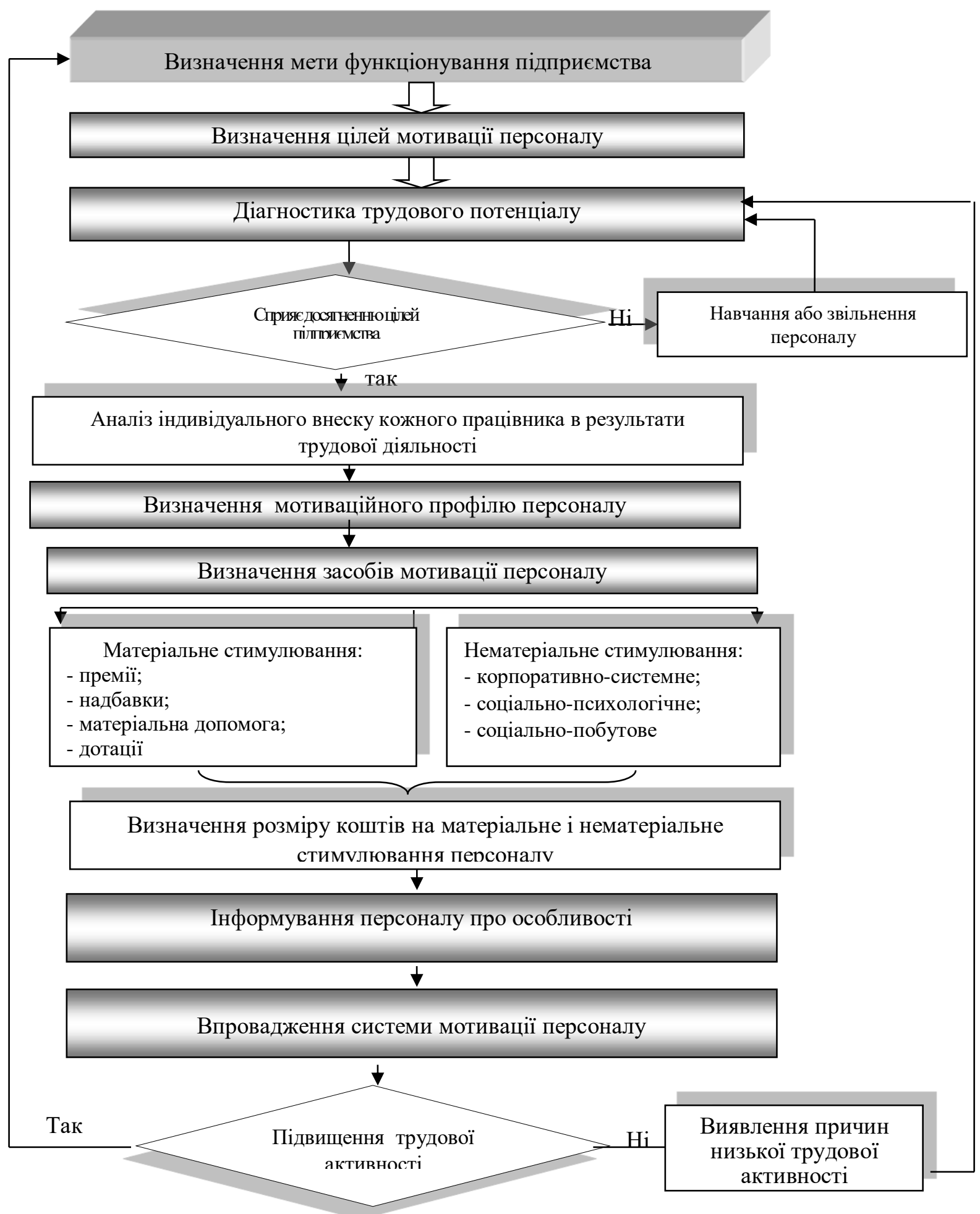

\section{Рисунок 2 - Науково-практичний підхід до розробки мотиваційної стратегії}

* авторська розробка підприємства 
Надалі проводиться діагностика трудового потенціалу підприємства 3 тим, щоб визначити його відповідність і реальну можливість досягти поставлених цілей розвитку підприємства. Одним із завдань при визначенні рівня розвитку трудового потенціалу $є$ вибір критеріїв його оцінки. В якості ключових критеріїв оцінки трудового потенціалу персоналу виступають дві його складові: кваліфікаційний потенціал (який складається 3 рівня освіти, професіоналізму, інтелекту і здібностей працівників) і особистісний потенціал (який включає в себе ставлення до праці, соціалізацію, особливості особистості, ціннісні орієнтації).

Найпоширенішим видом оцінювання трудового потенціалу $\epsilon$ атестація працівників, яка дає можливість менеджеру приймати обгрунтовані рішення щодо подальшого удосконалення існуючих форм мотивації працівників, роботи з планування ïx професійно-кваліфікаційного зростання, поліпшення існуючої системи відбору i розстановки персоналу, форм і методів навчання та підвищення кваліфікації і т. ін.

В результаті діагностики трудового потенціалу менеджер отримує мотиваційний портрет свого персоналу в цілому і окремих (ключових співробітників). На основі цього він може побудувати гнучку систему мотивації колективу. Грунтуючись на результатах подібної діагностики можна зробити ряд конструктивних висновків не тільки про те, як підвищити мотивацію персоналу до праці, а й як не припуститися його демотивації.

Якщо результати діагностики свідчать про наявність необхідних кількісноякісних характеристик персоналу для досягнення поставлених цілей, тоді доцільно провести аналіз індивідуального внеску кожного працівника в результати трудової діяльності. Якщо проведена діагностика трудового потенціалу виявить, що певні працівники за окремими видами компетенцій не готові активізувати свою трудову діяльність, то приймається управлінське рішення про навчання чи підвищення кваліфікації, або про звільнення працівника.

Важливою структурною компонентою мотиваційної стратегії $\epsilon$ визначення мотиваційного профілю персоналу. Мотиваційний профіль - це сукупність основних потреб і цінностей працівника, а також ступінь їх вираження [14]. Мотиваційний профіль складається шляхом зіставлення значимості ряду мотиваційних чинників. Такий підхід передбачає, що мотивація завжди індивідуальна. Складання загального переліку мотивів, найбільш актуальних для особистості співробітника, дає можливість при використанні відповідних засобів діагностики порівнювати певні фактори для конкретних співробітників в єдиній системі координат, прогнозувати і управляти процесами ефективної професійної реалізації. Водночас це дає можливість конструювати ефективні системи мотивації та стимулювання персоналу й визначати засоби мотивації персоналу, тому наступним етапом розробки мотиваційної стратегії $є$ визначення засобів мотивації персоналу

При визначенні засобів мотивації персоналу доцільно враховувати такі основоположні логічні посилки.

Мотивація персоналу пов'язана 3 природою стимулів до праці. Побудова схеми «потреби - інтереси - стимули - винагорода» допомагає зрозуміти, як здійснюється спонукання людини до активної праці. У будь-якій дії людини є спонукальний мотив. Людина вирішує, як йому вчинити, виходячи зі своїх потреб, внутрішніх побудників активності. Потреби людей розрізняються в залежності від рівня їх задоволення. Усвідомлення можливості реалізувати потреби породжує інтерес, який є реальною причиною дій. Реалізація інтересу може відбуватися за допомогою стимулу, тобто 
інструменту, за допомогою якого утворюється залежність між заохоченням людини і його діями.

Прагнення людини до поліпшення свого добробуту зумовлює збільшення трудового внеску, а, отже, і збільшення кількості, якості та результативності праці. Говорити про пріоритетність матеріальної мотивації в порівнянні з нематеріальною мотивацією, не завжди виправдано, хоча матеріальна мотивація має певні переваги. Зокрема, вона є найбільш універсальною, оскільки незалежно від статутного положення працівники більше цінують грошові заохочення i можливість розпоряджатися одержаними коштами. Мотивація персоналу не може бути чинною без задоволення матеріальних потреб, орієнтації на матеріальний інтерес працівників. Підвищення значення нематеріального стимулювання полягає в тому, що воно залишаються важливим каталізатором, здатним суттєво підвищити трудову активність та сприяти досягненню особистих цілей і цілей організації.

Після визначення дієвих засобів і стимулів мотивації персоналу слід зіставити обсяг розміру коштів на матеріальне і нематеріальне стимулювання персоналу 3 наявними фінансовими можливостями підприємства.

Після прийняття остаточного управлінського рішення про обрану модель матеріального і нематеріального стимулювання треба проінформувати персонал про особливості системи мотивації.

Завершальним етапом мотиваційної стратегії є впровадження системи мотивації персоналу на підприємстві.

Оцінку успішності реалізації мотиваційної стратегії персоналу здійснюють за основними напрямками ефективності, а саме: задоволеність роботою, задоволеність у розрізі ієрархії мотивів працівників, задоволеність системою стимулювання, трудова активність персоналу та т.ін.

Висновки. Таким чином, підсумовуючи вищевикладене можна зробити такі висновки.

Мотиваційна стратегія виступає стрижневою детермінантою управління персоналом підприємства за умови сприяння прогресивному розвитку особистості кожного працівника.

Мотиваційна стратегія передбачає встановлення об'єктивної залежності між винагородженням працівника та його внеском у зростання ефективності господарської діяльності підприємства. Таку залежність запропоновано впроваджувати через систему мотивації персоналу, яка передбачає застосування до працівника матеріального та не матеріального мотивування.

Мотиваційна стратегія розглядається як квінтесенція особливостей перспективної системи мотивування персоналу, при цьому акцент робиться на динаміці цих систем у міру успіхів або провалів в діяльності підприємства.

Впровадження запропонованої мотиваційної стратегії сприяє налагодженню відносин у колективі підприємства, підвищенню зацікавленості працівників у своїй роботі, підвищенню якості виконання працівниками функціональних обов'язків. Як наслідок, це призведе до збільшення прибутку підприємства, підвищення його конкурентоспроможності та посиленню конкурентної позиції.

Перспективи подальших досліджень. Подальшого дослідження потребує розробка науково-методичного інструментарію впровадження мотиваційної стратегії 3 урахуванням стратегічних змін та виявлення можливого опору персоналу щодо реалізації проекту стратегічних змін. 


\section{СПИСОК ВИКОРИСТАНИХ ДЖЕРЕЛ}

1. Одегов Ю. Г., Мотивация персонала / Ю.Г.Одегов, Г.Г.Руденко, С.Н.Апенько, А.И.Мерко. - М.: Альфа-Пресс, 2012. - 640 с.

2. Скачкова Л. С. Управление мотивацией персонала: подходы, модели, инструментарий / Л.С.Скачкова, Е.П. Костенко, С.В. Бутова, Е.В. Михалкина / под ред. Михалкиной Е. В. - Ростов-на-Дону: Изд-во «Содействие - XXI век», 2015. - 226 с.

3. Кравченко Е.С. Ключевые доминанты современных теорий мотивации персонала предприятия / Е.С.Кравченко, А.А.Скорик // Инновационное развитие экономики: предпринимательство, образование,наука : сб. науч. ст. / редкол. : Т. В. Борздова (отв. ред.) [и др.]. - Минск : ГИУСТ БГУ,2015. - С.85-89

4. Маслоу. А. Мотивация и личность. - М.: СПб: Евразия, 2014. - 478 с. Мерманн Элизабет Мотивация персонала. Инструменты мотивации для успеха организации. - М.: Гуманитарный центр - Москва, 2013. - 184 с.

5. Гуцан О.М. Дослідження сутності мотиваційних теорій: сучасні, теорії атрибуції та поля / О.М.Гуцан // Вісник Національного технічного університету „Харківський політехнічний інститут». - 2017. - № 24(1246). - С.26-30.

6. Губарев Р.В. Анализ современных теорий мотивации и стимулирования труда / Р.В..Губарев // Вестник УГУЭС. Наука. Образование. Экономика. Серия : Экономика. 2014. - № 1(7). - C.239-246

7. Литвинюк А. А. Мотивация и стимулирование трудовой деятельности. Теория и практика. Учебник. - М.: Юрайт 2014. - 398 с.

8. Ващенко, Н. В. Развитие торгового предприятия на основе формирования и реализации инновационного потенциала персонала: теория и методология : монография -. / Н. В. Ващенко. - Донецк : ДонНУЭТ. - Краматорск : Каштан, 2015. - 505 с.

9. Пицур Я.С. Мотивация труда и ее стимулювание в управлении персоналом / Я. С. Пицур, А. Л. Черченко // Економічний вісник. - 2018. - №1 . - С.153-158.

10. Любицкая В.А. Развитие мотивации труда персонала на основе индивидуализации инструментов стимулирования: монография / В.А. Любицкая, В.А. Бородин. Барнаул: АлтГТУ, 2014. 155 с.

11. Наумко Ю.С. Основные принципы мотивации труда и их воздействие на деятельность предприятия / Ю.С.Наумко // Глобальные и национальные проблемы экономики. -2016. - № 11. - С.641-644.

12. Питер Гаудж Исследование мотивации персонала. - М: Баланс Бизнес Букс, 2014.$272 \mathrm{c.}$

13. Расулова У.С. Мотивация сотрудников торгового предприятия / У.С.Расулова, Е. Жебокритский // Стратегия предприятия в контексте повышения его конкурентоспособности. - 2012. - №1(1) - С.226-228

14. Ричи Ш. Управление мотивацией / Ш. Ричи, П. Мартин / Пер. с англ. Климова Е. - М.: Юнити-Дана, - 2004. - 393 с. 